\title{
Seasonal cold adaptation dynamics of some carabid beetle species: Carabus granulatus, Pterostichus oblongopunctatus and Platynus assimilis
}

\author{
Angela Ploomi*, Irja Kivimägi, Eha Kruus, Ivar Sibul, Katrin Jõgar, \\ Külli Hiiesaar and Luule Metspalu
}

\begin{abstract}
Ploomi, A., Kivimägi, I., Kruus, E., Sibul, I., Jõgar, K., Hiiesaar, K., Metspalu, L. 2012. Seasonal cold adaptation dynamics of some carabid beetle species: Carabus granulatus, Pterostichus oblongopunctatus and Platynus assimilis. - Forestry Studies | Metsanduslikud Uurimused 57, 90-96. ISSN 1406-9954.
\end{abstract}

\begin{abstract}
Cold-hardiness can be measured by supercooling points - the temperature at which spontaneous freezing occurs. Seasonal changes in supercooling point were assessed in field-collected predacious carabid beetle species: Carabus granulatus L., Pterostichus oblongopunctatus L. and Platynus assimilis Payk. (Coleoptera: Carabidae). Supercooling ability of these beetles changed seasonally. The tested carabid beetles proved to belong to freeze-avoiding cryotype.
\end{abstract}

Key words: Coleoptera, Carabidae, cold-hardiness, supercooling.

Authors' address: Estonian University of Life Sciences, Kreutzwaldi 1, 51014 Tartu, Estonia; *e-mail: angela.ploomi@emu.ee

\section{Introduction}

Seasonal adaptation of insects depends on many abiotic factors, with temperature being the most critical factor aside of humidity and light (Danks, 2006, 2007). Insects survive low temperatures either by keeping their body fluids liquid below their ordinary freezing point (freeze avoidance), or by surviving the formation of ice in their tissues (freeze tolerance) (Bale \& Hayward, 2010; Lee, 2010). For species inhabiting in temperate and colder climates, the ability to supercool is undoubtedly the most important component of the overwintering strategy. At temperatures below $0{ }^{\circ} \mathrm{C}$, most insect species remain unfrozen because they supercool. Cold-hardiness can be measured by indices such as supercooling points (SCP), the temperature at which spontaneous freezing occurs (Danks, 2004).

Freeze-avoiding insects keep their body fluids liquid by removing ice nucleators that initiate ice formation, synthesizing antifreeze proteins to reduce the nucleation potential of seed crystals, and accumulating sugars and polyols, such as glycerol or trehalose, which also lower the crystallization temperature (defined as its supercooling point) and stabilize membranes at low temperatures (Vernon \& Vannier, 2002; Lee, 2010).

Freezing-tolerant insects survive ice formation in body tissues. Ice formation usually is confined to extracellular fluids, thus avoiding damage to intracellular components. Protective mechanisms for freezing resistance include elevated solute levels, presence of nucleating agents, and accumulation of cryoprotectants in body fluids. A number of freeze-tolerant insects have supercooling points in the range of $-8^{\circ} \mathrm{C}$ to $-10^{\circ} \mathrm{C}$, whereas some freeze-avoiding species supercool extensively, even to $-60^{\circ} \mathrm{C}$ or below. Insects that supercool are freezing- 


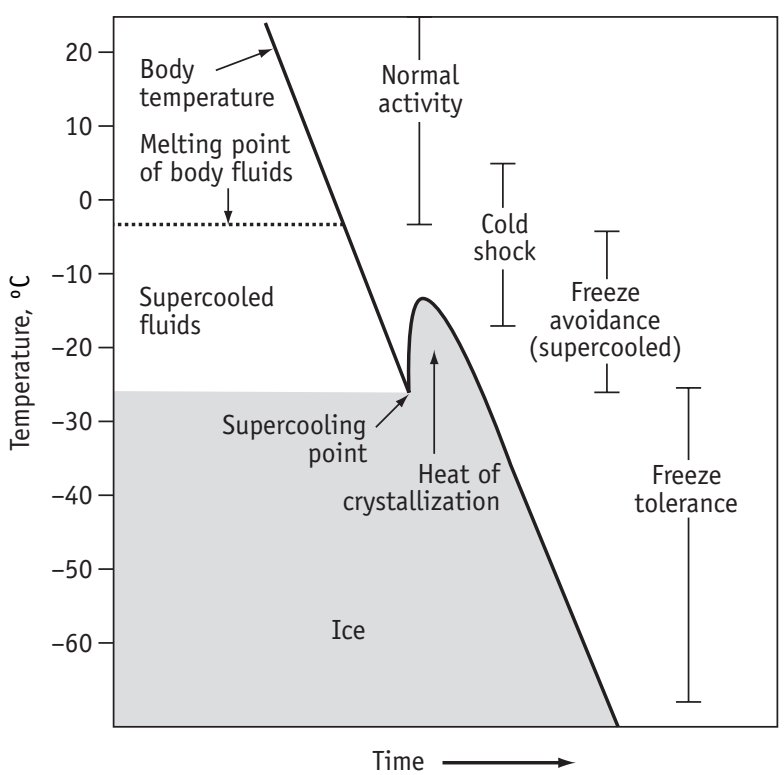

Figure 1. The generalized diagram of insect response to subzero temperatures. Insect body temperatures (heavy line) in relation to the melting point, the supercooling point, and the nucleation of ice in body fluids. The bars on the right convey general ranges of insect response to low temperatures, the top of the bar for the range of freeze tolerance and the bottom of the bar for freeze avoidance correspond to the supercooling point value illustrated in the center of the figure (Lee, 1989; Ellsbury et al., 1998).

Joonis 1. Putukas toimuvate temperatuurist põhjustatud muutuste näitlik diagramm (Lee, 1989; Ellsbury et al., 1998). Tugev must joon näitab putuka kehatemperatuuri (body temperature) muutusi temperatuuri langedes; viirutatud ala vastab jää (ice) tekkele ja olemasolule putuka organismis. Kehavedeliku sulamispunkt (melting point of body fluids) on temperatuur, mille juures sulab viimane kehas olev jääkristall. Enne allajahtumispunkti (supercooling point) ehk tegelikku külmumistemperatuuri on kehavedelikud (supercooled fluids) $0^{\circ} \mathrm{C}$ madalamas temperatuuris jahtunud olekus. AJP (allajahtumispunkti) juures eraldub kudede spontaansel külmumisel soojust (heat of crystallization). Putukate seisundid temperatuuri langemisel: normaalne aktiivsus (normal activity), külmašokk (cold shock), külmumise vältimine ehk külmatundlikkus (allajahtumine) (freeze avoidance (supercooled)), külmumise talumine (freeze tolerance). Külmašokk on jahtumine ilma külmumata, mõne külmatundliku putuka jaoks on pikaajaline madal temperatuur letaalne. Toimuvad muutused on tihedalt seotud aja- (time) ja temperatuurifaktoriga (temperature).

avoiding since they avoid freezing damage to body tissues only at a temperature above the supercooling point. Below the supercooling point, death results from ice formation in body tissues (Danks, 2004). These relationships are summarized in Figure 1 adapted from Lee (1989) and Ellsbury et al. (1998).

Cold-hardiness is equally important to pests and beneficial predators, includ- ing carabid beetles known of their sensitive reaction to environmental changes (Koivula, 2011). Carabid beetles (Coleoptera: Carabidae) are species rich and abundant in arable and forest habitats (Kromp, 1999). Carabid beetles are natural enemies attacking also both immature and adult pine weevils (Salisbury \& Leather, 1998; Dillon \& Griffin, 2008). Adult carabid beetles exhibit scarcely any activity in winter. Carabid 
species that inhabit cultivated fields spend the winter in soil or migrate into the field boundaries, whereas some species migrate into the forest (Thiele, 1977). The microenvironment of overwintering sites is at least as important in allowing winter survival as are physiological adaptations (Danks, 2004).

The aim of the present research was to study seasonal cold adaptation dynamics of carabid beetles Carabus granulatus L., Pterostichus oblongopunctatus L. and Platynus assimilis Payk. These species are farely common, all univoltine spring breeders (Luff, 1993) and represent three Carabidae genera. As they overwinter in older and partially decayed tree stumps they can be used as model species for Carabids of similar biology associated with both agricultural and forest ecosystems.

\section{Materials and methods}

\section{Insects}

Laboratory experiments were conducted to test three carabid species: Carabus granulatus (Linneaus 1758), Pterostichus oblongopunctatus (Linnaeus 1758) and Platynus assimilis (Paykull 1790). Adult insects were collected from their hibernating sites - tree stumps at wintertime (January) and from the field by using dry pitfall traps in spring (May) and autumn (September). Beetles were collected from the Tartu County, Estonia (ca. $58^{\circ} 26^{\prime} \mathrm{N}, 27^{\circ} 7^{\prime} \mathrm{E}$ ) in 2012. Samplings were performed early in the morning in cool weather (temperatures between $0{ }^{\circ} \mathrm{C}$ to $10^{\circ} \mathrm{C}$ ) and beetles were placed in the refrigerator at $4{ }^{\circ} \mathrm{C}$ immediately after the arrival to avoid major temperature fluctuations. To obtain field-collected beetles with empty guts, they were held for $24 \mathrm{~h}$ prior to the testing without food in plastic boxes filled with moisturized moss (for retaining moisture and providing hiding areas).

\section{Experimental design}

Together 216 beetles were recorded ( 9 variances $(3$ months $\times 3$ species $) \times 24$ insect replicates), the sex of insects were not deter- mined. For measuring supercooling points (SCPs), the beetles were positioned so that its integument (thoracic tergit) was in contact with the copper-constantan thermocouples-thermometer (RS-232 Data logger thermometer; TES Electrical Electronic, Taiwan), placed in glass vial closed by cap, and then transferred to circulator bath (Ministat 230w-2, Huber, Germany, $-33{ }^{\circ} \mathrm{C}$ to $+200{ }^{\circ} \mathrm{C}$ ). SCP was determined using a $0.5^{\circ} \mathrm{C} \mathrm{min}^{-1}$ cooling rate. The SCP was taken as the thermocouple recorded the lowest point before the emission of the latent heat of crystallization (when body fluids freeze). From each species five individuals were taken for determination of cold-hardiness strategies (freeze-tolerant or freeze-avoidance) by supercooling. When the temperature limit to supercooling is reached, heat of crystallisation appears, species who will survive recooling to the SCP have freeze-tolerant overwintering strategy, whereas those who will not survive are classified as freeze-avoiding species (Lee, 1989; Bale, 2002). The temperature curve was registered and saved by using data logger (Almemo 2890-9, Ahlborn Messund Regelungstechnik GmbH, Germany).

\section{Statistical analysis}

Supercooling points were tested for normality using the Kolmogorov-Smirnov Test. Statistical comparisons of the seasonal change of mean supercooling points of individuals were performed with repeatedmeasures one-way analysis of variance (ANOVA) followed by Fisher's LSD test, using STATISTICA 12 package. The collected data were analysed separately in each species. All means were considered significantly different at the $\mathrm{p} \leq 0.05$ level.

\section{Results and discussion}

Mean supercooling points are shown in Figure 2. Seasonal mean SCPs examined in C. granulatus were determined as follows: $-5.4^{\circ} \mathrm{C}$ (in January), $-5.2{ }^{\circ} \mathrm{C}$ (in May) and $-6.3^{\circ} \mathrm{C}$ (in September). The SCP in autumn 


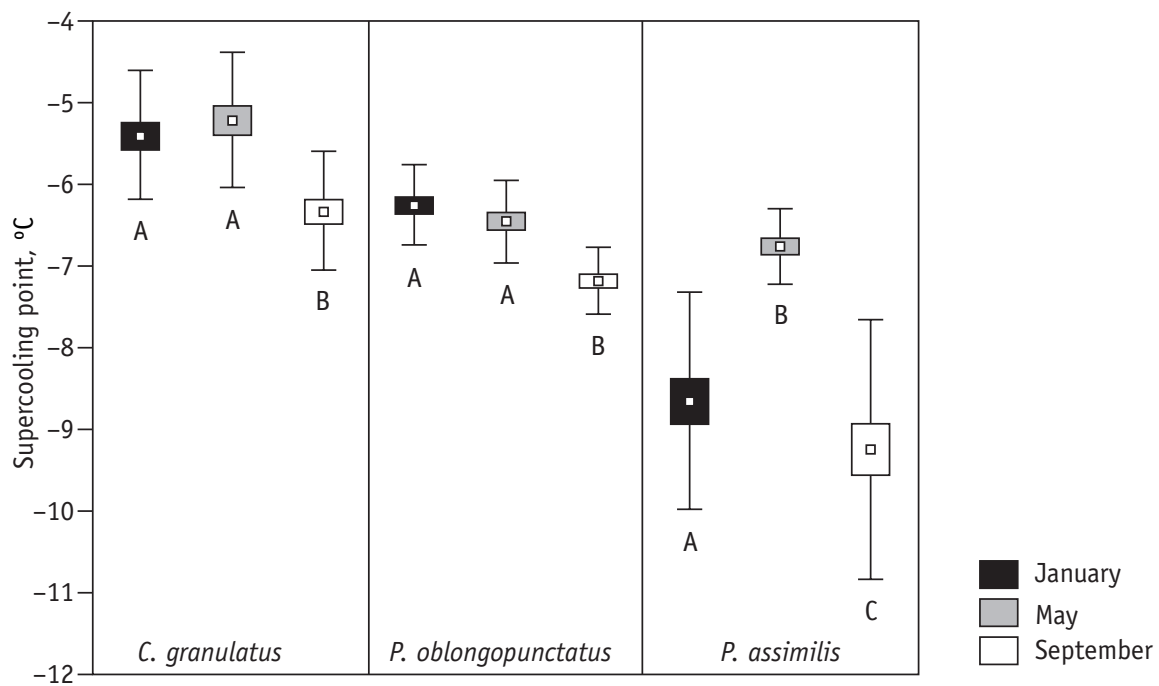

Figure 2. Supercooling seasonal dynamics of the carabid beetles $C$. granulatus, P. oblongopunctatus and $P$. assimilis. Columns with different letters are significantly different (ANOVA Fisher's LSD test, $p \leq 0.05)$. The differences were calculated between one species. Box-and-whisker plots: boxes show standard errors, whiskers are standard deviation bars, small box in the centre is mean.

Joonis 2. Sõmerjooksiku (C. granulatus), metsa-süsijooksiku (P. oblongopunctatus) ja süsi-ketasjooksiku (P. assimilis) külmakindluse sesoonne dünaamika. Allajahtumispunkte (supercooling point ${ }^{\circ} \mathrm{C}$ ) on võrreldud liigi piirres. Statistiliselt usaldusväärsed erinevused $(p \leq 0.05)$ on tähistatud erinevate tähtedega (ANOVA Fisher's LSD test).

differed significantly from that in January $\left(\mathrm{F}_{2,69}=14.17, \mathrm{p} \leq 0.05\right)$ and in May $(\mathrm{p} \leq 0.05)$, but there were no difference between winter and spring SCPs $(\mathrm{p}=0.43)$. The SCPs of P. oblongopunctatus ranged from $-6.3^{\circ} \mathrm{C}$ (May) to $-7.2{ }^{\circ} \mathrm{C}$ (September). Similarly to C. granulatus, supercooling of $P$. oblongopunctatus was lower in autumn compared to winter $\left(\mathrm{F}_{2,69}=25.49, \mathrm{p} \leq 0.05\right)$ and spring ( $\mathrm{p} \leq 0.05$ ), but also no differences between winter and spring supercoolings were found $(\mathrm{p}=0.44)$. The SCPs of $C$. granulatus and $P$. oblongopunctatus reached their minimum during autumn, and then raised by mid-winter to values as high as in spring. This pattern, which matches the autumndynamic strategy characterized by Merivee (1978), could be an physiological adaptive response in association with behavioral patterns of these species in Northern temperate condition. According to the autumn- dynamic strategy the greatest changes in cold-tolerance take place in autumn - the ability to supercool attains its winter maximum as early as autumn, in SeptemberOctober. In the course of winter (from November to April) it does not change noticeably. Supercooling capacity changes during the year and this is increasing when insect prepares for resting stage. Recorded SCPs were higher in January, compared to September. It is now known that many species complete diapause by mid-winter, but development is still suppressed by continuing low temperature. In such species, and those without a winter diapause, polyol concentrations and low SCP are usually maintained until spring, indicating that rising temperature triggers the reversible synthesis or degradation of the carbohydrates and consequent loss of cold-hardiness (Leather et al., 1993). 
The SCPs were lowest in the beginning of the overwintering (in September) in all examined insects: in C. granulatus $-6.3 \pm$ $0.73{ }^{\circ} \mathrm{C}$; in P. oblongopunctatus $-7.2 \pm 0.41{ }^{\circ} \mathrm{C}$ and in $P$. assimilis $-9.3 \pm 1.58^{\circ} \mathrm{C}$. In $P$. assimilis, beetles collected in May produced highest SCP $\left(-6.8^{\circ} \mathrm{C}\right)$, three months earlier in January the SCP was $-8.7^{\circ} \mathrm{C}$. There were significant differences between all the seasonal SCPs of P. assimilis beetles $\left(\mathrm{F}_{2,69}=27.17\right.$, $\mathrm{p} \leq 0.05)$. Earlier research by Kivimägi et al. (2009) has measured the January SCP at $5.5^{\circ} \mathrm{C}$ on $P$. assimilis, which indicates that the SCP and thus the cold-hardiness is regulated by environmental conditions and depends on the physiological state of the insect (Marshall \& Sinclair, 2012). For example carabid beetle Pterostichus brevicornis (Kirby 1837) was studied in Alaska, where it overwinters in decaying tree stumps and felled timber, although the habitat is at times partly covered with snow. These beetles may experience temperatures as low as $-60{ }^{\circ} \mathrm{C}$, with prolonged exposure to $-60^{\circ} \mathrm{C}$ over several weeks. Seasonally collected beetles showed SCPs from $-6{ }^{\circ} \mathrm{C}$ in summer (when freezing was fatal) to $-11{ }^{\circ} \mathrm{C}$, when beetles became freeze-tolerant (Baust \& Miller, 1970). The most striking feature of freezing intolerant insects is the seasonal increase in supercooling from summer through autumn to winter. Hiiesaar et al. (2012) found that supercooling ability of horseradish flea beetles Phyllotreta armoraciae (Koch 1803) is depending on their feeding status. In nature, most overwintering insects of the temperate or colder climates evacuate the digestive tract as a part of a multifactorial process that maximises supercooling in winter.

The tested carabid beetle species didn't survive the recooling until SCP, therefore they belong to freeze-avoiding insect group (Lee, 1989; Bale, 2002). The large majority of terrestrial arthropods that have been investigated are freeze-avoiding. Freezeavoiding species tend to (1) choose thermally buffered microsites for overwintering and (2) lower the temperature at which ice formation occurs (supercooling point) by producing antifreeze agents, minimizing internal nucleation sites, and avoiding contact with external ice (Sømme, 1999). Unseasonal cold in summer could cause some mortality in freeze avoiding insects, as there is not enough time for such insects to clear their guts and undergo the biochemical changes associated with the longterm acclimation for winter conditions (which is the process that may take days or weeks) (Sinclair et al., 2003). All the studied insect species overwinter in protected place - in tree stumps. After moving to overwintering sites beetles stop feeding, enabling them to increase their supercooling capacity. The greatest risk of mortality from low temperatures comes from the combination of no snow and low temperatures. Snow is an important insulator against low temperatures and a cover of snow or vegetation also helps to protect overwintering individuals against lethal temperatures, therefore snow cover could have significant matter in insects overwintering (Danks, 2004; Bale \& Hayward, 2010). According to the Estonian Meteorological and Hydrological Institute's (EMHI) measurements, the mean air temperature in insects overwintering time in January 2012 was $-5.8^{\circ} \mathrm{C}$ and snow cover $23 \mathrm{~cm}$. Consequently, overwintering mortality due to low temperature may be rare, for example, only in extremely severe snow-less winters. For a better interpretation of supercooling of studied carabid beetles, more research is required.

\section{Conclusions}

Cold adaptation dynamics of carabid beetle species C. granulatus, P. oblongopunctatus and $P$. assimilis varied seasonally. Carabid beetle species C. granulatus, P. oblongopunctatus and $P$. assimilis belong to freeze-avoiding cryotype. They are likely to survive unseasonal cold and overwintering could be harmful only in very cold snow-less winters. 
Acknowledgements. The research was supported by the Estonian Science Foundation (grant 9449), Estonian target financing project number SF170057s09 and State Forest Management forest protection project 8-2/ T12115MIMK (2012-2015).

\section{References}

Bale, J.S. 2002. Insects and low temperatures: from molecular biology to distributions and abundance. - Philosophical Transactions of the Royal Society of London (B), 357, 849-862.

Bale, J.S., Hayward, S.A.L. 2010. Insect overwintering in a changing climate. - The Journal of Experimental Biology, 213, 980-994.

Baust, J., Miller, L.K. 1970. Variations in glycerol and its influence on cold hardiness in the Alaskan carabid beetle Pterostichus brevicornis. - Journal of Insect Physiology, 16, 979-990.

Danks, H.V. 2004. Seasonal adaptations in arctic insects. - Integrative and Comparative Biology, $44,85-94$.

Danks, H.V. 2006. Insect adaptations to cold and changing environments. - Canadian Entomologist, 38, 1-23.

Danks, H.V. 2007. The elements of seasonal adaptations in insects. - Canadian Entomologist, 139, 1-44.

Dillon, A., Griffin, C. 2008. Controlling the large pine weevil, Hylobius abietis, using natural enemies. COFORD Connects: Silviculture and Forest Management, 15, 1-8.

Ellsbury, M.M., Pikul, J.L.Jr., Woodson, W.D. 1998. A review of insect survival in frozen soils with particular reference to soil-dwelling stages of corn rootworms. - Cold Regions Science and Technology, 27, 49-56.

Hiiesaar, K., Kaasik, R., Williams, I.H., Švilponis, E., Jõgar, K., Metspalu, L., Mänd, M., Ploomi, A., Luik, A. 2012. Cold hardiness of horseradish flea beetle (Phyllotreta armoraciae (Koch)). -Žemdirbystè=Agriculture, 99 (2), 203-208.

Kivimägi, I., Ploomi, A., Metspalu, L., Švilponis, E., Jõgar, K., Hiiesaar, K., Luik, A., Sibul, I., Kuusik, A. 2009. Physiology of a carabid beetle Platynus assimilis. - Agronomy Research, 7 (spec. iss. I), 328-334.

Koivula, M.J. 2011. Useful model organisms, indicators, or both? Ground beetles (Coleoptera, Carabidae) reflecting environmental conditions. - ZooKeys, 100, 287-317.
Kromp, B. 1999. Carabid beetles in sustainable agriculture: a review on pest control efficacy, cultivation impacts and enhancement. - Agriculture, Ecosystems and Environment, 74(1-3), 187-228.

Kuusik, A., Metspalu, L., Hiiesaar, K.1995. Insektitsiidide toimemehhanismide uurimine putukatel. (Studies on insecticide modes of action). Estonian Agricultural University, Tartu, 71-80. (In Estonian).

Leather, S.R., Walters, K.F.A., Bale, J.S. 1993. The Ecology of Insect Overwintering. Cambridge, UK. 300 pp.

Lee, R.E. 1989. Insect cold-hardiness: to freeze or not to freeze. - BioScience, 39 (5), 303-313.

Lee, R.E. 2010. A primer on insect cold-tolerance. - Lee, R.E., Denlinger, D.L. (eds.). Insects at low temperature. New York, USA, 3-24.

Luff, M.L. 1993. The Carabidae (Coleoptera) larvae of Fennoscandia and Denmark. - Fauna Entomologica Scandinavica, 27, 1-186.

Marshall, K.E., Sinclair, B.J. 2012. The impacts of repeated cold exposure on insects. - The Journal of Experimental Biology, 215, 1607-1613.

Merivee, E. 1978. Cold-hardiness in insects. Tallinn, Estonia, 186 pp. (In Estonian, Russian and English).

Merivee, E., Hansen, T., Kuusik, A. 1968. Mis saab putukatest talvel? (What will become of the insects in the winter?). - Eesti Loodus, 43, 723-728. (In Estonian).

Paljak, T. 2007. Õhutemperatuuri järskude muutuste statistiline ja sünoptiline analüüs külmal poolaastal ajavahemikul 1951-2006. (Rapid changes of air temperature and their statistical and synoptical analysis in cold period 1951-2006). Master thesis. Institute of Geography, University of Tartu. $52 \mathrm{pp}$. (In Estonian).

Salisbury, A.N., Leather. S.N. 1998. Migration of larvae of the large Pine Weevil, Hylobius abietis L. (Col., Curculionidae): Possible predation a lesser risk than death by starvation? - Journal of Applied Entomology, 122 (1-5), 295-299.

Sinclair, B.J., Addo-Bediako, A., Chown, S.L. 2003. Climatic variability and the evolution of insect freeze tolerance. - Biological Reviews, 78, 181-195.

Sømme, L. 1999. The physiology of cold hardiness in terrestrial arthropods. - European Journal of Entomology, 96, 1-10.

Thiele, H.U. 1977. Carabid beetles in their environment. A study on habitat selection by adaptations in physiology and behaviour. Berlin. 330 pp.

Vernon, P., Vannier, G. 2002. Evolution of freezing susceptibility and freezing tolerance in terrestrial arthropods. - Comptes Rendus Biologies, 325, 1185-1190. 


\title{
Mõne jooksiklase liigi külmakindluse sesoonne dünaamika: sõmerjooksik (Carabus granulatus), metsa-süsijooksik (Pterostichus oblongopunctatus) ja süsi-ketasjooksik (Platynus assimilis)
}

\author{
Angela Ploomi, Irja Kivimägi, Eha Kruus, Ivar Sibul, Katrin Jõgar, \\ Külli Hiiesaar ja Luule Metspalu
}

\section{Kokkuvõte}

Putukate sesoonne kohastumine sõltub paljudest teguritest, mille hulgas temperatuur on üheks kriitilisemaks faktoriks. Külmakindlus on väga oluline enamike parasvöötme putukate talviseks ellujäämiseks ning on inimese seisukohalt ühtviisi tähtis nii kasulikele kui kahjulikele organismidele (Danks, 2007). Jooksiklasi (Coleoptera: Carabidae) esineb liigirikkalt ja arvukalt põllumajandusmaadel ja metsades, kus nad mitmetoiduliste röövmardikatena on taimekahjurite tähtsad looduslikud vaenlased, näiteks söövad jooksiklased nii männikärsakate vastseid kui valmikuid (Salisbury \& Leather, 1998; Kromp, 1999; Dillon \& Griffin, 2008). Meie kliimavööndis on putukatele võimalike kriitiliste temperatuuride esinemise aeg küllaltki pikk: novembrist märtsini (Paljak, 2007), seetõttu on populatsiooni arvukuse hindamiseks oluline teada nende külmakindlust. Putukate külmakindlust iseloomustab allajahtumisvõime, mille all mõeldakse putuka kudede jahtumist $0^{\circ} \mathrm{C}$ madalamas temperatuuris, ilma et sellega kaasneks kudede külmumine (jääkristallide moodustumine). Putuka allajahtumisvõime mõõduks on tema allajahtumispunkt (AJP), s.o. temperatuur milles ta tegelikult külmub ning vabaneb kristallisatsioonisoojus, mis on termoelektriliselt registreeritav (Merivee et al., 1968; Kuusik et al., 1995; Danks, 2007). Jooksiklased lõpetavad peale talvituskohtadesse jõudmist toitumise, mis võimaldab neil oma allajahtumisvõimet tõsta. Antud eksperimendi eesmärgiks oli määrata kolme jooksiklase liigi - sõmerjooksiku (C. granulatus), metsasüsijooksiku ( $P$. oblongopunctatus) ja süsiketasjooksiku (P. assimilis) külmakindluse sesoonne dünaamika ja külmakindluse strateegia.

Sõmerjooksiku keskmine AJP oli $-5.4^{\circ} \mathrm{C}$ (jaanuaris), $-5.2{ }^{\circ} \mathrm{C}$ (mais) ja $-6.3^{\circ} \mathrm{C}$ (septembris). Metsa-süsijooksiku AJP-d varieerusid $-6.3^{\circ} \mathrm{C}$ (mais) kuni $-7.2^{\circ} \mathrm{C}$ (septembris). Mõlema uuritud liigi AJP-d olid sügisel madalamad kui talvel ja kevadel, samas talve ja kevade näitajate vahel erinevus puudus. Süsi-ketasjooksiku AJP oli kõige kõrgem maikuus $\left(-6.8^{\circ} \mathrm{C}\right)$, kolm kuud varem jaanuari oli AJP $-8.7^{\circ} \mathrm{C}$. Erinevatel kuudel määratud süsi-ketasjooksiku AJP-d erinesid statistiliselt üksteisest. Uuritud jooksiklaste liigid hukkuvad kui peale AJP käigus eralduvat soojenemist temperatuuri uuesti kuni AJP temperatuurini jahutada, seega on tegemist külmumist vältivate ehk külmatundlike liikidega (Lee, 1989; Bale, 2002). Tõenäoliselt on katsetatud jooksiklaste liikidele ohtlik allajahtumispunktist madalamate temperatuuridega lumevaene talv. 